\title{
EDUCATIONAL THOUGHT OF FRIEDRICH AUGUST FROEBEL
}

\author{
Dr.Rayees Ahmad Dar \\ Dept.Of. Education, University Of Kashmir, India \\ Rayees78601@gmail.com
}

Keywords: Philosophy, Aims, Curriculum, Teaching Methods, Role of Teacher, Discipline, Kindergarten

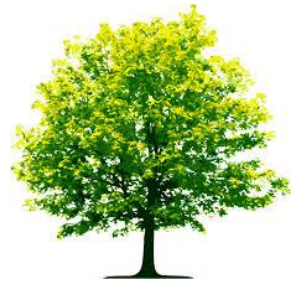

\begin{abstract}
A B S T R A C T
The purpose of conducting the present study was to analyze the role and contribution of model world citizen-Friedrich August Froebal. The main objective of the study was to examine the role of the philosopher in a different perspective. In conducting this study, the philosophical and historical methods were employed. The primary and secondary sources related to Froebel's educational philosophy were evaluated after detailed analysis. The general philosophical tools for the study, which were used in the present investigation are induction, deduction, dialectical, analysis and synthesis. The study revealed that educationists and teacher's duty is not only to acquaint the students with subject matter, principles and generalization, but also inculcate in them a sense of research and criticism so that they will be able to acquire the habit of free and impartial judgment. The study further revealed that object of education is the realization of the faithful, pure, inviolable and hence holy life. Education should fit the individual for a full life.
\end{abstract}

Citation: Rayees Ahmad Dar (2018). Educational Thought Of Friedrich August Froebel. International Journal of Advanced Multidisciplinary Scientific Research (IJAMSR ) ISSN:2581-4281 Vol 1, Issue 9, November, 2018, \#Art.914, pp 36-42

\section{Introduction}

A reflective western thinker, philosopher a prolific writer Friedrich Wilhelm Froebal August was born in the village of Oberweisbach on April 21, 1782 in southern Germany. His father was not very affectionate to him and his mother died when he was only about nine months. His father remarried when Froebel was only four years of age. His father was indifferent towards him and his step mother`s treatment was very unfair. Thus, he was deprived of parental affection, love and care. At the age of eleven he was adopted by his uncle who was associated with a Church near his village. At the age of 14 he was apprenticed for two years to a forester. It was here that his love for nature grew. At seventeen he joined the University of Jena, where he was profoundly influenced by the idealistic philosophy of Fitche and Schelling. On account of financial difficulty, he discontinued his studies. 


\section{International Journal of Advanced Multidisciplinary Scientific Research (IJAMSR) ISSN:2581-4281}

Froebel had to make various attempts in order to find a vocation permanently agreeable. Ultimately, he understood that teaching work was the only activity that answered his inner longings. From 1807 to 1810 he spent most of his time at the school of Pestalozzi at Yverdun. Thus, Froebel learnt in detail the methods and principles of Pestalozzi. Froebel did not agree with Pestalozzi and regarded the latter's ideas as tentative and lacking in clearness and solidity. However, it will have to be admitted that this contact with Pestalozzi prepared him for his own educational reforms.

After Pestalozzi model at Yverdun, Froebel opened a school for boys in 1817 at Keilhan incorporating his principles of elementary education. This school was not successful. So he left this school to his assistants and in 1831 went to Switzerland. He wanted to devote his life to the reform of pre-school training and in 1836 he returned to Germany. In 1837 he opened his first Kindergarten in the mountain village of Blankenburg. From this time till his death he devoted his whole time to the founding of Kindergarten, the training of teachers of Kindergarten and elaborating his methods and principles, and devising apparatuses for Kindergarten.

Only a few could accept his views. They were not widely accepted in Germany because of their extremely democratic nature and because they could not be understood fully. He was in correspondence with some of his followers in the United States, and he declared that only in the United States his ideas would have full expression. At a ripe age of seventy, he died in 1852.

\section{Need and Importance}

The special feature of philosophy is that it comes out of specific experiences, special circumstances and situations. This is the reason why different persons adopted different philosophies of life in accordance with the specific circumstances and conditions wherein they spent their lives. They not only accepted their philosophies as mental beliefs, but they tried to translate their principles and philosophical beliefs into practice also. Realities of life are essential as thoughts. A child must study both science and philosophy to know and understand truth and reality of natural and human phenomena.

The kind of education which the nineteenth century calls „the new education ${ }^{e e}$ is based on the works of many thinkers and Frobel is one among them. He for the first time applied the idea of unity and spontaneous growth to education. He believed that Divine essence of man should be unfolded, brought out and lifted into consciousness. Education should lead and guide man to clearness concerning him and in himself, to peace with nature, and to unity with God; hence, it should lead him to knowledge of himself and of mankind, and to the pure and holy life to which such knowledge leads.

His view that education is a growth and a growth from within of the native powers of the child held a great influence on the later thought of teaching theory and practice. His doctrine that knowledge is not the end of education, but the means towards the end minimized the value of verbalism. His recognition of the educational value of play, self activity, creative work, social participation and learning by doing are psychologically, 


\section{International Journal of Advanced Multidisciplinary Scientific Research (IJAMSR) ISSN:2581-4281}

socially and practically sound. Froebel was a person who never ceased to systematize, symbolize, idealize, identities and analyzed among all facts and phenomena of the universe. He made life more simple, clear and more recognizable.

All the best tendencies of modern thought in education culminate in what was said and done by Froebel. So the purpose of this study was to see to what extent the educational views of this great and eminent philosopher is relevant to modern times.

\section{Objectives of the Study}

- To study the Friedrich Froebel`s educational ideas in different perspective.

- To study the relevance of his educational philosophy to the contemporary society.

\section{Review}

While going through the review of the studies conducted on different thinkers, many researchers have been conducted on Plato, Aristotle, Paulo Frier, Ivan Illich, Roussea. There is almost no study conducted on educational ideas of Friedrich Froebel.

\section{Methodology}

Philosophical and historical methods has been used and apart from that both primary as well as secondary sources related to Friedrich Wilhelm August Froebel has been employed for the collection of data. Accordingly, the data has been collected, scrutined and critically analyzed for interpretation and drawing conclusions.

\section{His Educational Ideas:}

In Froebel education is a stage in the evolution of the child. Education helps him to elevate him to a higher level and be a useful member of society. By education, he understands that he is part of nature. Though The education he becomes conscious of his unique existence and begins to seek his own place in the human society. He becomes ambitious to play his own part in the interaction of the society.

According to Froebel, education is a development from within. Education is a development from which man ${ }^{\text {ee }}$ life broadens until it has related itself-to nature, until it enters sympathetically into all activities-of the society, until it participates in the achievement of the race and aspirations of humanity. To Froebel, education is growth from within. It is a development by which an individual realizes that he is one unit of the all-encompassing unity."It is development by which man"s life broadens until it has related it to nature; until it enters sympathetically into all activities of society, until it, participates in the achievements of the race and aspirations of humanity."

Education is to unfold the child ${ }^{\text {ee }}$ s innate powers and awaken his spiritual nature so that he may have a spiritual union with God. Regarding the functions of education, Froebel remarks, "Education should lead and guide man to clearness, concerning him and in himself, to peace with nature, and to unity with God. It should lift him to knowledge of himself and of mankind, to knowledge of God and a nature and to the pure and holy life." 


\section{International Journal of Advanced Multidisciplinary Scientific Research (IJAMSR) ISSN:2581-4281}

\section{Aims Of Education}

Froebel was clear about the aim of education as he stated, 'the purpose of education is to encourage and guide man as a conscious, thinking and perceiving being in such a way that he becomes a pure and perfect representation of that divine inner law through his own personal choice. Education must show him the ways and means of attaining that goal. He believed that humans are essentially productive and creative, and fulfillment comes developing these in harmony with God and the world. He sought to encourage the location of an educational environment that involved practical work and the direct use of materials. It was only then that Froebel felt that understanding would develop.

Froebel believed that education should aim at all round development of the child. It is in this way, the child will develop into a good citizen. The objective of education is the realization of a faithful, pure, inviolable and hence holy life.

Froebel has an idealistic philosophy; according to him there is law - of unity which is one - of the fundamental laws of education. Education must enable the child to understand the principle - of unity and enable him to have a spiritual union - with God. Education should lead and guide men, to clearness concerning himself and in himself, to peace with nature and to unity with God.

Froebel aimed that education must enable every child to understand his environment. Education should lift him to knowledge of himself and of mankind, to knowledge of God and nature. To Froebel education is not a preparation for future life, but understanding the life around the individual. It will help the child to develop his individuality through social atmosphere.

\section{Curriculum}

All-round development being his aim of education, Froebel wanted that the curriculum at the childhood stage should consist of four main divisions;

(a) Religion; which he says should be the basis of all education. No other knowledge is possible without it.

(b) Natural Science; nature, he has often repeated, is the manifestation of God. Its study will mean the contemplation of outer facts, while religion requires inner contemplation. Therefore, both are necessary to have a complete man. Insight into nature reveals the laws that rule in human life. This creates a sense of the reign of law. "From every object of nature and life there is a way to God". In this study of natural science, he also emphasizes the importance of mathematics. In his opinion, this subject is a connecting link between the mind of man and the natural world. Mind and mathematics, he says, are inseparable as the soul and religion.

(c) Languages: these help in establishing the inner living connection among the diversities of things and thus complete the work of education.

(d) Expressional work: Froebel believed that there is a need for the Expression of the soul in outward form. This expression may take the form of singing, drawing, painting and modeling. Manual work helps in the development of skill, creative power and exercise of the muscles. He attached the spiritual importance to hard work. He recommended gardening, woodwork, leather work, clay modeling and art in the shape - of 
drawing, painting and singing in the education (curriculum). His curriculum for children consists of mainly those activities and subjects where the child expresses himself- freely and yet learns something such as construction, play, acting, writing, storytelling and hundreds other things.

\section{Methods Of Teaching}

Froebel's method of teaching is based on four basic principles:

- Principle of Self Activity: According to Froebel, the real development of the child is possible only through self-activities. It gives joy, freedom, contentment and peace. It enables the child to reveal his personality and attain self-realization. Froebel believed that a child was not to indulge in an activity that was suggested by parents or teachers. He stresses that the child should be given full freedom to carry out his own impulses and decisions.

- Principles of Play way Method: Play is the most important activity of the childhood period when the child is free from the burden. Different qualities such as cooperation, leadership, tolerance, freedom, mutual adjustment etc. are developed. The play is very important for proper physical, mental, moral, motor and social development of the children.

- Principles of Social Participation: From the very beginning, children should be trained to lead a group life and to live well in the society in developing different aspects of personality. Froebel asserted that the real education can take place in the company of others because the life of the individual is an integral part of the society. He believed that all social institutions like the home, the school, the church and the state, etc. are the agencies of development of the individual wherein he is to realize the unity in diversity.

- Principles of Freedom: For Froebel in good education, in genuine instruction, in true training, the necessity should call forth freedom. Full freedom is given to the expression of activities and educational development of a child. He should not be interfered from outside.

\section{Role Of The Teacher}

Froebel did not ignore the status and role of teacher in educational process. He believed that teacher as moralist substitutes for parents. For the child, the teacher is like a pastor, prophet and priest. He is at once guide, teacher, and administrator of a sacred ritual. Froebel believed that person who enters into the professional of teaching has to play different roles in the welfare of the students and society. The teacher should be sympathetic and show kindness with his pupils. Froebel believed that teacherec saim must be to make of his pupils and students capable, as independent thinkers. Teachers are expected to promote cultural tolerance and teach students the social skills they need to get along with one another. Overall, the teacher should undertake his responsibility in accordance with some basic principles, that a teacher 


\section{International Journal of Advanced Multidisciplinary Scientific Research (IJAMSR) ISSN:2581-4281}

is a father figure for pupils. Briefly speaking, Froebel advocated that teacher has to perform the different roles - instructor, designer, manager, master of content, role model etc for the welfare of pupils.

\section{Discipline}

Froebel was against the represessionistic discipline, he said that good education is possible only when the children have complete freedom of self-activity. Froebel regarded self-activity as a process of creative development. For this purpose, he laid stress on atmosphere of freedom. Children love to work, play, sing or dance freely. There should be no-interference in their activities. No-activity should be thrust upon them. They are free to spend their time in a way they like. But at the same time, they must remain conscious about their obligations. There should be self-control of freedom, keeping those freedoms of others in view. Froebeles entire theory of discipline rests upon the notion of full freedom and free choices.

\section{Kindergarten - A Concept of Experimental School}

Froebel was the first man in the history of education to give the idea of Preschool Education in the form of Kindergarten - "Children`s Garden”. Froebel started a school at Blankenberg (Germany) for small infants and called it Kindergarten means a garden of children ${ }^{e e}$ and was designed to be a place where children were „allowed to blossom“e. Froebel regarded this school as a garden and the teacher as a gardener who carefully tends the little human plants under his care and helps them grow in beauty and perfection. There is an atmosphere of self activity, play and joy in the school. Children are given freedom in activity while Froebel saw this as a gentle type of education, it was really quite structured. Kindergarten was devised to help children with their optimal growth and development - by providing an environment to realize their potentialities to the fullest extent. In the Kindergarten all attempts are made for unfolding the innate potentialities of children. But such unfoldment is guided, not molded and children`s development is nourished and nurtured, not imposed and forced. The motive of Kindergarten is "Come, Let us, Live for the Children".

\section{Relevance With Contemporary}

Froebal has made a valuable contribution to educational theory and practice. Froebel's play-way method finds place in the teaching learning process at all stages of education and in all subjects. Froebel lived for children, worked for children and died for children. Froebel laid stress on the study of the nature of the child, his instincts and impulses. Modern educator is very careful to see that adequate scope is provided for the free play of instincts and impulses of children. He introduced play way in the activities and today we find that the principle of playway has been accepted by every educator. Froebel was the first educator to make the self - activity as the basis of education. Learning by doing is the slogan of the day. Froebel $^{\text {ee }} \mathrm{s}$ educational principles have been accepted as basic for education at all levels from primary stage to university. Modern education will ever remain indebted to Froebel. All the best tendencies in modern education can be traced back to what Froebel stood for centuries ago. The Froebel was first who drew the attention of the society towards the education of every young child. 


\section{International Journal of Advanced Multidisciplinary Scientific Research (IJAMSR) ISSN:2581-4281}

\section{References}

1. Ahuja Ram (2011) Research methods, Rawat publication.

2. Best John W. (2011) Research in education, PHI learning private Ltd New Delhi.

3. Dewey John (1907-1915) Froebel"s Educational principles. University of Chicago, pp 111-127

4. Dewey, J. (1990). The school and society and the child and the curriculum(Expanded ed.). Chicago: The University of Chicago Press.

5. Froebel, Friedrich. (1896). The education of man. Trans. W.N. Hailman. New York: Appleton.

6. Heidersheim (1989) Froebel"s Formal educational system . Lawrence university of London press

7. Heiland Helmut (1982) Froebel and his inflance on education .international Bureau of education, vol. xx111,no 34 .

8. Helmet Heiland (1982) Froebal and his Influence on Education, Retrieved from www.ibc.unesco.org

9. James I., Hughes (1897) Froebel"s education laws for all teachers. International educational serioe

10. Jung CG (1961). Freud and Psychoanalysis. Princeton, NJ: Princeton University Press.

11. Jung CG (1971). Psychological types. Princeton, NJ: Princeton University Press.

12. Juri and Yoneyama (2012) A critical analysis of the reception and implementation of Froebel"s educational philosophy in Japan. International journal of early childhood.

13. Kneller, George F. (1971). Introduction to the philosophy of education. New York: John Wiley \& Sons, Inc.

14. Koul Lokesh (2009) Methodology of education research, Vikas publication.

15. Lawrence, Evelyn. Ed. (1969). Friedrich Froebel and the English education. London: Routledge \& Kegan.

16. Lilley, I. (1976). Friedrich Froebel: A Selection from his Writings, London: Cambridge University Press.

17. Logon Friedrich M. (1950) Kindergarten and Bauhas, Atlantic Publication.

18. Matsukawa, Y. (1990). The First Japanese Kindergartens. International Journal of Early Childhood. 22 (1, pp. 32-37.

19. Polito, Theodora, (1995) Froebel"s illuminations on kindergarten children relatedness to nature. education, USA, Green wood

20. Reinbek (1982) Friedrich Froebel"s educational system. Appleton publication London .

21. Sniegoski, Stephen J. (2004) Froebel and Early Childhood Education in America. US Dept. of education resource information centre.

22. Staff (1998) A - Study of Educational thoughts of Friedrich Froebel. University of Arkansas.

23. Stein HT (1997). Was Adler influenced by Froebel? Retrieved October 6, (2005), http://ourworld.compuserve.com/homepages/hstein Ifcrebel.-htm.

24. Susan E. Blow. (1895) the songs and music of Friedrich froebel"s mother play Germany, D. apleton, compan

25. Taneja V.R (2006) Educational thinkers, Atlantic publication.

26. Tujii, T. (2006). Best Kindergarten, Japan: Okutabu.

27. Vannel Anglus Mac (1900) Educational theories of Herbart and Froebel, Retrieved from www.archive.org/stream

28. W. T. Harris (1903) . Friedrich Froebel"s Education by Development. New Yark, Green wood.

29. Wollons, R. (2000). Kindergartens and cultures: the global diffusion of an idea, London: Yale University Press. 